\title{
Interactive comment on "Satellite ice extent, sea surface temperature, and atmospheric methane trends in the Barents and Kara seas" by Ira Leifer et al.
}

\section{Anonymous Referee \#2}

Received and published: 12 June 2018

Review of "Satellite ice extent, sea surface temperature, and atmospheric methane trends in the Barents and Kara Seas" by Ira Leifer et al.

\section{General comments}

The submitted paper looks rather interesting. The authors carried out study in considering one of the current warming consequences, namely: increasing methane concentrations. They made a detailed enough review of the relevant literature and presented rather detailed analysis of the subject. However, the paper needs reworking in some ways listed below.

The introduction and methods seem to be too long. These two chapters take about 11 
pages of text compared to about 10 pages for the results and discussions.

Subchapter 2.3 Setting looks redundant, especially for the chapter describing materials and methods, except the very last paragraph.

Some inaccurate using of Barents Sea currents names take place in the paper (see below).

Drawing conclusions about variability in currents taking into account only variability of SST is incorrect.

Most figures are too small, of a poor quality and, as a result, hardly readable.

Specific comments

Line 26: The Murman Coastal Current flows mainly eastward. The Murman Current also flows eastwards towards Novaya Zemlya, and in the eastern part, the flow (usually called as the Novaya Zemlya Current) is generally northeastwards along the slopes of the North Kanin, Goose and Novaya Zemlya Banks.

Line 27: SST depends on both currents and air temperature. Air temperature plays a key role in SST variability in shallow waters of the south-eastern Barents Sea and southern Kara Sea. Heat fluxes between ocean and atmosphere are important there.

Line 55 and on: There is one confusing term in the paper, namely: albedo. Usually, surface albedo is defined as the ratio of irradiance reflected to the irradiance received by a surface, and ranges from about 0.9 for fresh snow to about 0.04 for charcoal, one of the darkest substances. In the paper, albedo seems to be defined as the ratio of irradiance absorbed to the irradiance received, doesn't it?

Line 60: The word "Arctic" is unnecessary in the phrase "the East Siberian Arctic Sea".

Line 330: Novaya Zemlya is an archipelago, not an island, and includes two large islands (Southern and Northern) and lots of small. 
Line 327: The phrase "The relatively shallow (230-m average depth) Barents Sea (Fig. 4 ) is characterized by a deep Arctic shelf. . ." is ununderstandable.

Line 335 and on: The Norwegian, Greenland, Barents, Kara and some other seas are included in the Arctic Ocean. Therefore, it is better to say the Arctic Basin (the central area of the Arctic Ocean beyond all these seas) in this context.

Line 338: There is no current in the Barents Sea called "Bear Island Channel Current". There are warm North Cape current flowing eastwards in the Bear Island Trough and cold Bear Island Current flowing southwest along the southeastern slope of the Spitsbergen Bank.

Line 340: The Grand bank mentioned in the paper is commonly known as the Great bank.

Lines 385-387: There is a repetition in this place: "cooler surface water ... flows in NZCC and exit through the Kara Strait". The NZCC abbreviation expansion needs being done at the first mention in line 385.

Line 403: The cold Bear Island Current flows there, not the Persey Current that is located further northeast.

Line 404: Both focus areas (A8 and A10) are only influenced by Atlantic waters, the Persey Current does not influence them (this is clearly seen in picture $4 a$ ).

Line 418: The Saint Anna Trough is a correct name.

Line 418: The focus areas are shown in figure 4, not 3.

Line 430: According to bathymetry shown in figure $4 \mathrm{a}$, focus area 7 covers the shelf slope, and focus area 8 covers depths of more than $200 \mathrm{~m}$. They do not seem to cover banks.

Lines 435 and 451: All three northern focus areas (A1-A3) are located south of the FJL, none of them are east of the FJL. 
Line 450: According to figure 7, trends are almost absent in some areas ( $\mathrm{A} 3$ and $A 6$, for example).

Line 453: This is a moot point that trends in SST are consistent with strengthening or weakening of currents. Advection of waters with higher temperatures and local conditions effect these trends as well. For example, the volume flux into the Barents Sea was rather low from 2007 to 2015 (ICES. 2017. Report of the Working Group on the Integrated Assessments of the Barents Sea. WGIBAR 2017 Report 16-18 March 2017. Murmansk, Russia. ICES CM 2017/SSGIEA:04. 186 pp.).

Lines 483-484: Measured volume fluxes through the Barents Sea Opening (see reference above) are weakly consistent with this statement.

Lines 489-490: The mentioned importance is not clear from figure 9 at all.

Line 491: It is ununderstandable what current is mentioned (BIC). Along the eastern coastline of the Svalbard, the cold East Spitsbergen Current only flows southwards.

Lines 498-499: This is the Bear Island Current, not the Persey Current.

Line 540: The Kara Sea is ice-free in September and almost ice-free in August but not in July (even during the last warm period). In July, the northern and northeastern parts of the Kara Sea as well as the area close to the eastern coastline of the Novaya Zemlya Archipelago are still ice-covered often.

Lines 614-617: The authors need to pay more attention to winds over the Barents and Kara Seas; the role of atmospheric circulation seems to be underestimated.

Line 682: The evidence of the statement that currents are strengthening is not provided. The phrase "larger oceanographic trends" is ununderstandable.

Lines 731 and 732: There is some mess in using "northwest" and "northeast". The FJL and St. Anna Trough are in the northeastern Barents Sea, not in the northwestern. The southwestern and southern parts of the Barents Sea are ice-free year round, but

Printer-friendly version

Discussion paper 
not the northeastern part.

Figure 4a: The East Greenland Current looks like having the wrong direction. This current is flowing southwards (Skjoldal H.R. (Ed.). 2004. The Norwegian Sea Ecosystem. Tapir Academic Press, Trondheim. 559 pp.; Dickson R.R., Meincke J., Rhines P. (Eds). 2008. Arctic-Subarctic Ocean Fluxes: Defining the Role of the Northern Seas in Climate. Springer, Dordrecht. 736 pp.). The detailed description of the Barents Sea currents is also presented in: Jakobsen T., Ozhigin V.K. (Eds). 2011. The Barents Sea: ecosystem, resources, management: Half a century of Russian-Norwegian cooperation. Tapir Academic Press, Trondheim. 825 pp. (scanned version of this book is available at https://brage.bibsys.no/xmlui/handle/11250/109444).

Figure 6: The caption mentions figure $3 c$ that is absent.

Figures 7, 8 and 9: There is no explanation for symbols and lines on the graphs.

Figures 8 and 9: There are data series and their rolling-averages, but not trends.

Technical corrections

Lines 2 and 93: The word "seas" needs writing with a capital letter.

Lines 487 and 781: The word "Sea" needs writing in the plural.

Line 512: A mistype in the Persey Current name.

Figure 2: One mistype needs correcting: Jul should be replaced with Jan in the legend.

Figure 5: A mistype in the PINRO abbreviation.

Interactive comment on The Cryosphere Discuss., https://doi.org/10.5194/tc-2018-75, 2018. 